\title{
Methionine requirement of kittens given amino acid diets containing adequate cystine
}

\author{
BY KATHERINE A. SMALLEY, QUINTON R. ROGERS \\ AND JAMES G. MORRIS \\ Departments of Physiological Sciences and Animal Sciences, University of California, \\ Davis, California 95616, USA
}

(Received 11 May 1982 - Accepted 2 December 1982)

1. Six purified amino acid diets containing $6.0 \mathrm{~g}$ cystine $/ \mathrm{kg}$ and the following levels of $\mathrm{L}-\mathrm{methionine}(\mathrm{g} / \mathrm{kg}$ diet): $2 \cdot 1,2 \cdot 7,3 \cdot 3,3 \cdot 9,4 \cdot 5,9 \cdot 0$ were presented to twelve weanling kittens (six male and six female) for six periods of $10 \mathrm{~d}$ each. Kittens were assigned to the diets in accordance with a $6 \times 6$ balanced Latin-square design.

2. Body-weight gains of males and females attained apparent plateaux at $3.3 \mathrm{~g}$ methionine $/ \mathrm{kg}$ diet and were respectively (mean \pm SEM) $22 \pm 4$ and $18 \pm 2 \mathrm{~g} / \mathrm{d}$. Daily food intakes attained apparent plateaux at $2.7 \mathrm{~g}$ methionine $/ \mathrm{kg}$ diet for male and female kittens and were $63 \pm 10$ and $49 \pm 4 \mathrm{~g} / \mathrm{d}$ respectively. Nitrogen retentions (calculated as dietary- $\mathrm{N}$ intake minus faecal- and urinary- $\mathrm{N}$ excretion) attained apparent plateaux at $3.9 \mathrm{~g}$ methionine $/ \mathrm{kg}$ diet for both male and female kittens and were $0.85 \pm 0.15$ and $0.65 \pm 0.05 \mathrm{~g} / \mathrm{d}$ respectively.

3. Previous work has shown that the kitten's L-methionine requirement, in a diet lacking cystine, is $7.5 \mathrm{~g} / \mathrm{kg}$ diet. Our results indicate that the kitten's L-methionine requirement is $3.9 \mathrm{~g} / \mathrm{kg}$ diet when $6.0 \mathrm{~g}$ cystine $/ \mathrm{kg}$ is provided, thus approximately $50 \%$ of the animal's sulphur amino acid requirement can be met by cystine.

Methionine is an essential amino acid for most species of animals and, therefore, must be supplied in the diet for normal growth and physiological function. Cystine, conversely, is considered to be a dispensable amino acid because cysteine can be synthesized from methionine by the trans-sulphuration pathway. Cystine spares methionine by decreasing the amount of methionine required for maximal growth; the metabolic explanation for this is unclear. Finkelstein \& Mudd (1967) found that the addition of cystine to a low-methionine diet resulted in a significant decrease in the hepatic activity of cystathionine synthase (EC 4.2.1.22) and, to a lesser extent, a decrease in cystathionase (EC 4.2.1.15) activity (two enzymes important in the conversion of methionine to cysteine). More recently, however, Stipanuk \& Benevenga (1977) found that the addition of cystine to a diet given to rats resulted in a depression of cystathionine synthase activity by $34-47 \%$ of control values. However, their findings, with regard to protein synthesis, suggested that the decrease in methionine oxidation was more likely due to a greater utilization of methionine for protein synthesis than to a decrease in cystathionine synthase activity. Methionine cannot be completely replaced by cystine since methionine cannot be synthesized from cystine; therefore, the use of a basal diet containing excess cystine permits a determination of the minimal methionine requirement. This value, combined with a value for the methionine requirement without cystine, allows a determination of the proportion of the total sulphur amino acid requirement that can be met by cystine.

Although early studies of the feline's $\mathrm{S}$ amino acid metabolism indicated that methionine was dispensable for the adult cat (Dymsza \& Miller, 1964; Rambaut \& Miller, 1965), more recent findings have shown that weight loss occurs when a methionine-free diet is presented to kittens or adult cats and is reversed by the addition of methionine to that diet. Ritter \& Owens (1974) found that methionine supplementation (from 5.25 to $10.87 \mathrm{~g} / \mathrm{kg}$ ) of a casein-gelatin-based diet, containing $0.6 \mathrm{~g}$ cystine $/ \mathrm{kg}$, resulted in weight gains greater than those from unsupplemented diets (personal communication with these authors indicates that the cystine content was incorrectly stated in the abstract as $6.0 \mathrm{~g} / \mathrm{kg}$ ). Studies by Teeter 
Table 1. Composition of post-weaning diet

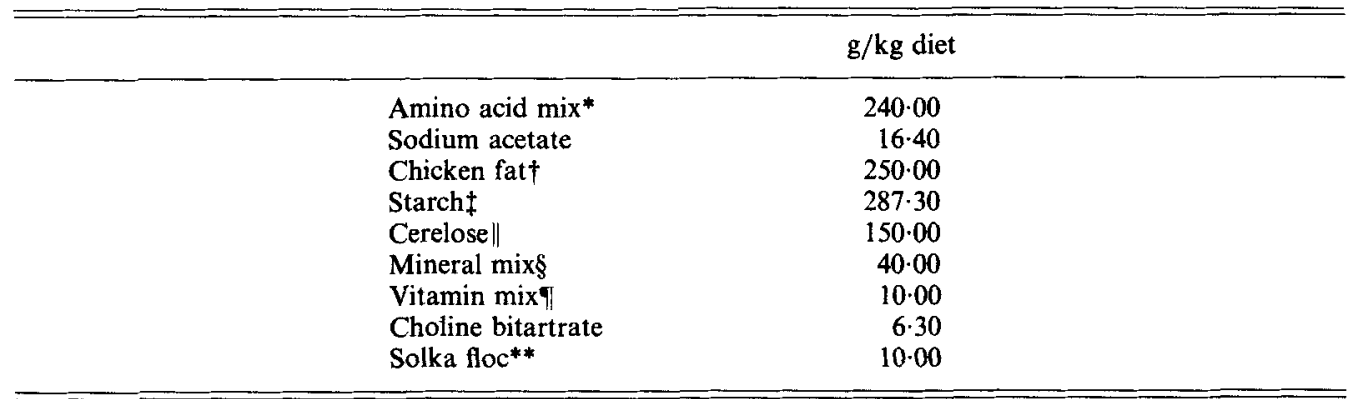

* Composition of standard amino acid mix (g/kg diet): Arg-hydrochloride 20.00, Cys 6.0, Met 9.0, His-hydrochloride monohydrate $6 \cdot 0$, Ile 9.0, Leu $12 \cdot 0$, Lys-hydrochloride $14 \cdot 0$, Phe $7 \cdot 0$, Tyr 6.0, Thr 10.0, Trp 3.0, Val 9.0, Ala 19.0, Asp 10.0, Asn 20.0, Glu 20.0, Gln 30.0, Gly 20.0, Pro 10.0 (Vega Biochemicals, Tuscon, Arizona).

+ Rendered stewing chicken fat; distributed by Valley Fresh in Turlock, California.

$\ddagger$ Melojel, food grade maize starch; National Starch and Chemical Company, Bridgewater, New Jersey.

$\|$ Cerelose, dextrose 2001; Corn Products, Englewood Cliffs, New Jersey.

$\S$ Composition of mineral mix (g/kg mix): $\mathrm{CaHPO}_{4} 474 \cdot 0, \mathrm{~K}_{2} \mathrm{HPO}_{4} 100 \cdot 0, \mathrm{CaCO}_{3} 130 \cdot 0, \mathrm{MgSO}_{4} 50 \cdot 40, \mathrm{KCl}$ $75 \cdot 0, \mathrm{NaCl} 139 \cdot 0$, trace minerals $31 \cdot 60$. The individual trace elements provided as $\mathrm{g} / \mathrm{kg} \mathrm{mineral} \mathrm{mix:} \mathrm{MnSO}_{4} \mathrm{H}_{2} \mathrm{O}$ $0.48, \mathrm{ZnSO}_{4} 7 \mathrm{H}_{2} \mathrm{O} 5 \cdot 56, \mathrm{CuSO}_{4} 5 \mathrm{H}_{2} \mathrm{O} 1 \cdot 0$, ferric citrate $3 \mathrm{H}_{2} \mathrm{O} 6 \cdot 0$, pentacalcium orthoperiodate $0 \cdot 18, \mathrm{SnCl}_{2} 2 \mathrm{H}_{2} \mathrm{O}$ $0 \cdot 10, \mathrm{Na}_{2} \mathrm{SeO}_{3} \mathrm{O} \cdot 03,\left(\mathrm{NH}_{4}\right)_{6} \mathrm{Mo}_{7} \mathrm{O}_{4} 4 \mathrm{H}_{2} \mathrm{O} 0 \cdot 05, \mathrm{CrCl}_{3} 6 \mathrm{H}_{2} \mathrm{O} 0 \cdot 32, \mathrm{NiCl}_{2} 6 \mathrm{H}_{2} \mathrm{O} 0 \cdot 3, \mathrm{NaF} 0 \cdot 14, \mathrm{NH}_{4} \mathrm{VO}_{3} 4 \mathrm{H}_{2} \mathrm{O} 0 \cdot 025$.

1) Composition of vitamin $\mathrm{mix}(\mathrm{mg} / \mathrm{kg}$ diet): retinol palmitate 80 , cholecalciferol 5 , DL- $\alpha$-tocopherol 640 , menadione 15 , thiamin hydrochloride 25 , riboflavin 10 , pyridoxine 10 , nicotinic acid 100 , calcium pantothenate 20 , myo-inositol 200, folic acid 10, cobalamin 50, biotin 1, ascorbic acid 200, taurine 200 .

** Solka floc (non-nutritive fibre) was added at $10 \mathrm{~g} / \mathrm{kg}$ of the complete diet.

et al. (1978a) and Rogers \& Morris (1979) in which crystalline L-amino acid diets were presented also showed a restoration of the weight gain once methionine was added back to the deficient diet.

On the basis of the growth response to their methionine-supplemented casein-gelatin diets, Ritter \& Owens (1974) suggested that $9.0 \mathrm{~g}$ methionine $/ \mathrm{kg}$ in the presence of $0.6 \mathrm{~g}$ cystine $/ \mathrm{kg}$ was sufficient for the growing cat. Teeter $e t$ al. $(1978 \mathrm{~b})$, on the basis of gain and gain: feed value, reported the methionine requirement of the young cat to be between 3.0 and $4.5 \mathrm{~g} / \mathrm{kg}$ diet in the presence of $6 \mathrm{~g}$ cystine $/ \mathrm{kg}$ diet. The objective of the present experiment was to refine this estimate of the methionine requirement of the growing kitten using nitrogen retention and growth.

\section{MATERIALS AND METHODS}

Male and female specific pathogen-free kittens were weaned at 6 weeks of age and then presented a semi-purified amino acid diet (Table 1 ) which provided $6.0 \mathrm{~g} \mathrm{~L}$-cystine $/ \mathrm{kg}$ and $9.0 \mathrm{~g} \mathrm{~L}$-methionine $/ \mathrm{kg}$. After 2-3 weeks of adjustment to the diet and to the individual stainless-steel metabolism cages $(0.6 \times 0.6 \times 0.8 \mathrm{~m}$ high), six male and six female kittens were selected for the study. Selection was based on a weight gain of at least $10 \mathrm{~g} / \mathrm{d}$ during the post-weaning period and a body-weight not greatly in excess of $1 \mathrm{~kg}$. The mean ( \pm SEM) values for body-weight of the male kittens was $975 \pm 87 \mathrm{~g}$ and of the female kittens was $799 \pm 28 \mathrm{~g}$ at the beginning of the experimental period. The twelve kittens were grouped according to sex (i.e. one group of six male kittens and a second group of six female kittens). These groups were treated as two replicates because of previously observed differences in food intake and growth rate between male and female kittens. Each group of six kittens was assigned to the experimental diets in accordance with a $6 \times 6$ balanced Latin-square design (Cochran \& Cox, 1957), which allows for analysis of carry-over, period, individual 


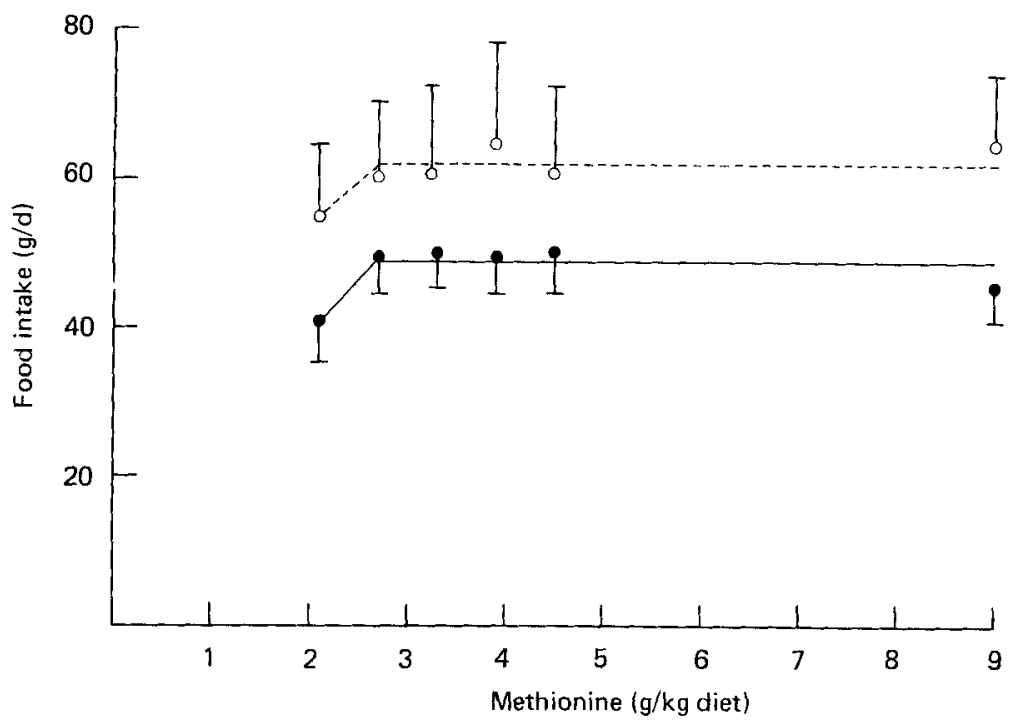

Fig. 1. Mean food intake of six male $(O)$ and six female $(O)$ weanling kittens given six different levels of dietary methionine $(6.0 \mathrm{~g}$ cystine $/ \mathrm{kg}$ diet $)$. Standard error of each mean is indicated by the vertical bar. Pooled SEM $\$ 3 \cdot 15$, ㅇ $1 \cdot 73$.

and treatment effects. Food intake and weight were measured daily. Daily weight gain was calculated by least-squares regression of daily body-weights for each 10-d period. Faecal material and urine were collected daily and were pooled over the first $5 \mathrm{~d}$ and the second $5 \mathrm{~d}$ of each period. To minimize bacterial contamination and $\mathrm{N}$ loss of these samples, $6 \mathrm{M}$-hydrochloric acid was used as a preservative in the urine collection cups and faecal material was frozen each day after collection. $\mathrm{N}$ determinations were performed on samples of diet, faeces and urine by the Kjeldahl procedure (Association of Official Agricultural Chemists, 1975). $\mathrm{N}$ retention was calculated by subtracting urinary and faecal $\mathrm{N}$ from dietary-N intake. Hair loss was not considered in the calculation of $\mathrm{N}$ retention, due to the difficulty in obtaining a complete collection.

\section{DIETS}

The six experimental diets were isonitrogenous and isoenergetic to the amino acid diet given post-weaning (calculated to provide $21 \mathrm{MJ}$ metabolizable energy $/ \mathrm{kg}$ diet), and differed only in the level of methionine and alanine in each diet. The amino acid mixture used in these diets differs considerably from that used by Hardy et al. (1977); the increased information on specific amino acid requirements for the kitten has permitted decreases in the amounts of many of the essential amino acids in the mixture. All experimental diets contained $6 \mathrm{~g}$ cystine $/ \mathrm{kg}$ and either $2 \cdot 1,2 \cdot 7,3 \cdot 3,3.9,4.5$ or $9.0 \mathrm{~g}$ methionine $/ \mathrm{kg}$. $\mathrm{N}$ as alanine was added to the diets in proportion to the decrease in methionine-N. All experimental diets contained choline in excess of (US) National Research Council (1978) recommended concentrations ( $3 \mathrm{~g}$ choline $/ \mathrm{kg}$ diet) to provide an excess of methyl groups. Taurine was added at $0.2 \mathrm{~g} / \mathrm{kg}$ diet in the vitamin mix and inorganic sulphate at $0.5 \mathrm{~g} / \mathrm{kg}$ diet in the mineral mix. Food and water were available ad lib. throughout the study.

\section{RESULTS}

The responses of food intake, weight gain, and $\mathrm{N}$ retention to the level of dietary methionine are shown in Figs. 1, 2 and 3 respectively. Results for male and female kittens are plotted separately since male kittens eat more and gain more weight than female kittens. Two of 


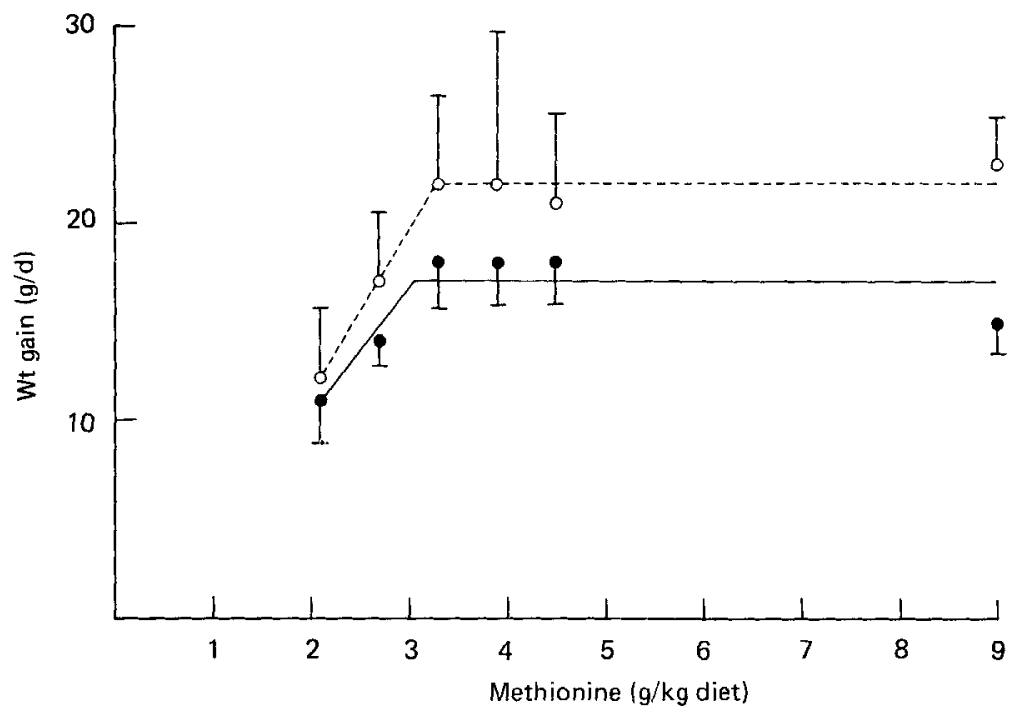

Fig. 2. Mean weight gain of six male $(O)$ and six female $(\bullet)$ weanling kittens given six different levels of dietary methionine $(6.0 \mathrm{~g}$ cystine $/ \mathrm{kg}$ diet $)$. Standard error of each mean is indicated by the vertical bar. Pooled SEM: $\sigma^{\star} 3 \cdot 55,011 \cdot 86$.

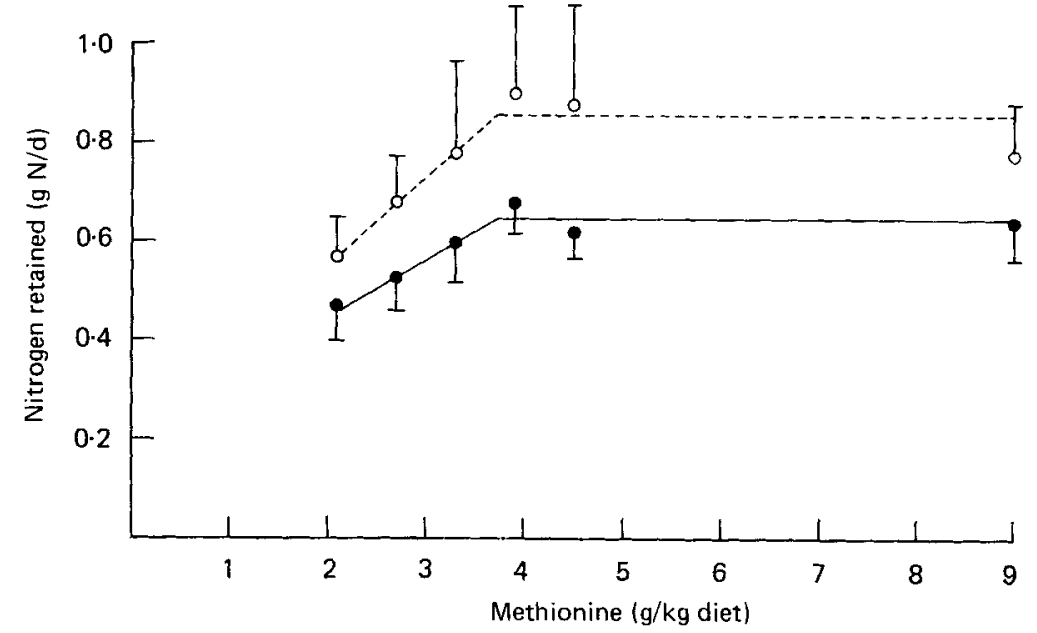

Fig. 3. Mean nitrogen retention of six male $(O)$ and six female $(\bullet)$ weanling kittens given six different levels of dietary methionine $(6.0 \mathrm{~g}$ cystine $/ \mathrm{kg}$ diet). Standard error of each mean is indicated by the vertical bar. Pooled SEM: $\partial \hat{0} 0 \cdot 10$,

the male kittens ate large amounts of food resulting in larger variability among males than females.

The methionine level of the diet had little effect on food intake (Fig. 1). Except for the lowest level of methionine $(2 \cdot 1 \mathrm{~g} / \mathrm{kg})$, mean $( \pm \mathrm{SEM})$ food intake by both sexes was relatively constant for the experimental diets at $63 \pm 10 \mathrm{~g} / \mathrm{d}$ for male kittens and $49 \pm 4 \mathrm{~g} / \mathrm{d}$ for female kittens.

Weight gain showed a linear increase in response to concentrations of methionine in the diet from 2.1 to $3.3 \mathrm{~g} / \mathrm{kg}$ diet (Fig. 2). Above $3.3 \mathrm{~g}$ methionine $/ \mathrm{kg}$ diet, weight gain reached a plateau at $22 \pm 4 \mathrm{~g} / \mathrm{d}$ in male kittens and $17 \pm 2 \mathrm{~g} / \mathrm{d}$ in female kittens. 
$\mathrm{N}$ retention increased linearly between 2.1 and $3.9 \mathrm{~g}$ methionine $/ \mathrm{kg}$ diet and thereafter levelled off. $\mathrm{N}$ retention was $0.85 \pm 0.15 \mathrm{~g} \mathrm{~N} / \mathrm{d}$ for male kittens and $0.65 \pm 0.05 \mathrm{~g} \mathrm{~N} / \mathrm{d}$ for female kittens when dietary methionine was $3.9 \mathrm{~g} / \mathrm{kg}$ diet or greater.

Analysis of variance of the individual $6 \times 6$ Latin squares was performed by a method which allows for correction of the sum of squares for residual effects from the previous period (see Cochran \& Cox, 1957, section 4.6a). Residual effects were not significant for any of the criteria examined, therefore these $5 \mathrm{df}$ were pooled with the error term, and food intake, weight gain and $\mathrm{N}$ retention were re-analysed for male and female cats. Female cats showed a significant $(P<0.05)$ change in food intake, weight gain and $\mathrm{N}$ retention in response to L-methionine level; however, male cats did not exhibit significant changes in these criteria. This may be due to the much larger variability of response seen in the male cats.

Orthogonal comparisons of data with unequal intervals were determined using coefficients obtained by the method of Grandage (1958). Single degree orthogonal comparisons indicated that a significant amount of the variation about the treatment means could be accounted for by the quadratic model for weight gain and $\mathrm{N}$ retention of both sexes.

\section{DISCUSSION}

Based on an examination of the results of $\mathrm{N}$ balance, $3.9 \mathrm{~g} \mathrm{~L}$-methionine $/ \mathrm{kg}$ diet (with $6.0 \mathrm{~g}$ cystine $/ \mathrm{kg}$ ) appears to be adequate to provide maximal $\mathrm{N}$ retention for the weanling kitten. This is one full increment higher than that which was adequate on the basis of weight gain alone ( $3.3 \mathrm{~g} \mathrm{~L}$-methionine $/ \mathrm{kg}$ ). These results are consistent with those of Teeter $e$ t al. $(1978 b)$ which indicated that the kitten's L-methionine requirement is between 3.0 and $4.5 \mathrm{~g} / \mathrm{kg}$ diet in a diet containing $6.0 \mathrm{~g}$ cystine $/ \mathrm{kg}$. In the present study we were able to define the requirement more precisely because of the use of smaller increments of L-methionine and because $\mathrm{N}$ retention in addition to weight gain was used as the criteria. $\mathrm{N}$ retention is more definitive when determining $\mathrm{N}$ or amino acid requirements because it relates to changes in total body- $\mathrm{N}$ and not simply to changes in weight gain which may result from variations in non-nitrogenous components.

Schaeffer $e t$ al. (1982) determined the L-methionine requirement of the weanling kitten with a crystalline amino acid diet lacking cystine. The levels of $\mathrm{L}$-methionine used were $(\mathrm{g} / \mathrm{kg}$ diet): $4 \cdot 5,7 \cdot 0,8 \cdot 0,9 \cdot 0,10 \cdot 0,15 \cdot 0$. On the basis of $\mathrm{N}$ retention, the kitten's L-methionine requirement, when the diet contained no cystine, was $7.5 \mathrm{~g} / \mathrm{kg}$. Using this value $(7.5 \mathrm{~g} / \mathrm{kg}$ diet) and the L-methionine requirement of $3.9 \mathrm{~g} / \mathrm{kg}$ diet from the present study, it can be calculated that $45-50 \%$ of the total $\mathrm{S}$ amino acid requirement of the weanling kitten can be met by cystine.

In the study by Teeter $e t a l .(1978 b)$ the response to the experimental diets was highly variable and weight gain actually decreased at levels of methionine above $4.5 \mathrm{~g} / \mathrm{kg}$. When L-methionine was provided at $4.5 \mathrm{~g} / \mathrm{kg}$ diet, weight gain (mean \pm SEM) was $275 \pm 28 \mathrm{~g} / 8-\mathrm{d}$ period; at $6.0 \mathrm{~g} / \mathrm{kg}$ diet, weight gain dropped to $185 \pm 44 \mathrm{~g} / 8$-d period; and at $9.0 \mathrm{~g} / \mathrm{kg}$ weight gain was even lower at $143 \pm 62 \mathrm{~g} / 8$-d period. These levels of methionine are not considered high enough to cause methionine toxicity and the subsequent loss in body-weight. Consistently good weight gains were seen in the study by Schaeffer et al. (1982) when experimental diets contained from 7.5 to $15.0 \mathrm{~g} \mathrm{~L}$-methionine $/ \mathrm{kg}$.

We have found that responses (i.e. weight gain, food intake and $\mathrm{N}$ retention) to experimental diets differ between male and female kittens. Teeter et al. (1978b) did not indicate the gender of the kittens used in their experiment. If the experimental groups of Teeter et al. (1978 b) were assigned without regard to equal sex distribution then this factor may account partially for the great variability in weight gain in their experiment.

The requirement of the cat for $\mathrm{L}$-methionine is somewhat higher than that of other 
mammals. The rat, a species studied in detail, has a minimal requirement for methionine of $1.7 \mathrm{~g} / \mathrm{kg}$ diet in the presence of $2.6 \mathrm{~g}$ cystine $/ \mathrm{kg}$ (Sowers et al. 1972). This particular study was done with crystalline amino acid diets, but other studies done with barley-or casein-based diets have indicated that the requirement is between 2.7 and $3.0 \mathrm{~g} / \mathrm{kg}$ diet (Shannon et al. 1972; Ngwira \& Beames, 1978). Using $\mathrm{N}$ balance as an index, Baker et al. (1969) determined the L-methionine requirement of $9-\mathrm{kg}$ pigs given an isolated soya-bean-protein diet. Maximal $\mathrm{N}$ retention occurred at $1.7 \mathrm{~g} \mathrm{~L}$-methionine and $3.3 \mathrm{~g} \mathrm{L-cystine} / \mathrm{kg}$ diet. More recently, the $\mathrm{L}$-methionine requirement of immature beagles was determined using crystalline L-amino acids. Weight gain, $\mathrm{N}$ retention and feed efficiency indicated a minimal requirement of $2.0 \mathrm{~g}$ methionine $/ \mathrm{kg}$ in a diet containing $6.0 \mathrm{~g}$ cystine $/ \mathrm{kg}$ (Burns \& Milner, 1981).

Birds and fish tend to have higher requirements for methionine than mammals. For birds, this high requirement for $\mathrm{S}$ amino acids is probably a reflection of the high cystine content of feathers. Graber et al. (1971) determined the maxium replacement value of cystine for methionine in young chickens to be $56-67 \%$ of the total $\mathrm{S}$ amino acid requirement. From the study of Graber et al. (1971) the calculated minimal L-methionine requirement of chickens was $2.5 \mathrm{~g} / \mathrm{kg}$ for a diet containing excess cystine. The requirement of Chinook salmon (Oncorhynchus tshawytscha) hatchlings was determined by maximal weight gain to be $6.0 \mathrm{~g}$ methionine $/ \mathrm{kg}$ in the presence of $10.0 \mathrm{~g}$ cystine $/ \mathrm{kg}$ diet (Halver et al. 1959). The hatchling green sea turtle (Chelonia mydas) has a similarly high L-methionine requirement of $4.9 \mathrm{~g} / \mathrm{kg}$ diet containing $10.8 \mathrm{~g} \mathrm{~L}$-cystine $/ \mathrm{kg}$ (Wood \& Wood, 1977).

D'Mello (1976) outlined a simple method for making interspecies requirement comparisons which involves plotting methionine plus cystine intake in $\mathrm{mg} / \mathrm{d} v$. weight gain. This method accounts for some of the differences in rates of protein deposition, maintenance and rates of amino acid ingestion, and was shown to be an improved method for comparing the requirements for $\mathrm{S}$ amino acids of the rat, chick and turkey. The slope of our data is similar to that obtained by D'Mello, but the regression is displaced to the right. This indicates that the cat has a similar efficiency of utilization of $S$ amino acids for growth, but that the maintenance requirement is somewhat higher than that for rat, chick and turkey.

While little is known about feline intermediary metabolism in general, our present knowledge of $\mathrm{S}$ amino acid metabolism in the cat indicates that it has some unique features. The cat, unlike other species, under certain conditions may not synthesize sufficient taurine to maintain normal retinal function (Hayes et al. 1975). Taurine is synthesized from cysteine, but cysteine sulphinic acid decarboxylase (EC 4.1.1.29), an enzyme important in this conversion, has been shown to have low activity in the liver of the cat (Knopf et al. 1978). The cat also differs from other species in that it excretes felinine, a branched-chain S-containing amino acid. Felinine is not found in tissues of the cat and is believed to be synthesized in the kidney (possibly from cystine) and excreted in the urine. The activities of many of the enzymes involved in feline $S$ amino acid metabolism are unknown. Undoubtedly a more complete understanding of $S$ amino acid metabolism in the cat will lead to an explanation for its unusually high methionine requirement.

The authors wish to thank John Bryan for his help in supervising the analysis of biological samples for this study.

This research was supported in part by funding from the Pet Food Institute, Washington, D.C.

Association of Official Agricultural Chemists. (1975). Official Methods of Analysis, 12th ed. Washington, DC: Association of Official Agricultural Chemists.

Baker, D. H., Clausing, W. W., Harmon, B. G., Jensen, A. H. \& Becker, D. E. (1969). J. Anim. Sci. $29,581$. 
Burns, R. A. \& Milner, J. A. (1981). J. Nutr. 111, 2117.

Cochran, W. G. \& Cox, G. M. (1957). Experimental Designs, 2nd ed. New York: John Wiley \& Sons, Inc.

D'Mello, J. P. F. (1976). Br. Poult. Sci. 17, 157.

Dymsza, H. A. \& Miller, S. A. (1964). Fedn Proc. Fedn Am. Socs exp. Biol. 23, 186.

Finkelstein, J. D. \& Mudd, S. H. (1967). J. biol. Chem. 242, 873.

Graber, G., Scott, H. N. \& Baker, D. H. (1971). Poult. Sci. 50, 1450.

Grandage, A. (1958). Biometrics 14, 287.

Halver, J. E., DeLong, D. C. \& Mertz, E. T. (1959). Fedn Proc. Fedn Am. Socs exp. Biol. 18, 527.

Hardy, A. J., Morris, J. G. \& Rogers, Q. R. (1977). J. Nutr. 107, 1308.

Hayes, K. C., Carey, R. E. \& Schmidt, S. Y. (1975). Science 188, 949.

Knopf, K., Sturman, J. A., Armstrong, M. \& Hayes, K. C. (1978). J. Nutr. 108, 773.

National Research Council (1978). Nutrient Requirements of Cats. Washington, DC: National Academy of Sciences.

Ngwira, T. N. \& Beames, R. M. (1978). Br. J. Nutr. 40, 443.

Rambaut, P. C. \& Miller, S. A. (1965). Fedn Proc. Fedn Am. Socs exp. Biol. 24, 373.

Ritter, S. M. \& Owens, F. N. (1974). J. Anim. Sci. 39, 981.

Rogers, Q. R. \& Morris, J. G. (1979). J. Nutr. 109, 718.

Schaeffer, M. C., Rogers, Q. R. \& Morris, I. G. (1982). J. Nutr. 112, 962.

Shannon, B. M., Howe, J. M. \& Clark, H. E. (1972). J. Nutr. 102, 557.

Sowers, J. E., Stockland, W. L. \& Meade, R. J. (1972). J. Anim. Sci. 35, 782.

Stipanuk, M. H. \& Benevenga, N. J. (1977). J. Nutr. 107, 1455.

Teeter, R. G., Baker, D. H. \& Corbin, J. E. (1978a). J. Anim. Sci. 46, 1287.

Teeter, R. G., Baker, D. H. \& Corbin, J. E. (1978b). J. Nutr. 108, 291.

Wood, J. R. \& Wood, F. E. (1977). J. Nutr. 107, 171. 